\title{
NITROGEN, CALCIUM AND PHOSPHORUS BALANCE OF BROILERS FED DIETS WITH PHYTASE AND CRYSTALLINE AMINO ACIDS ${ }^{1}$
}

\author{
Balanço de nitrogênio, cálcio e fósforo em frangos de corte \\ recebendo dietas com fitase e aminoácidos cristalinos ${ }^{1}$
}

\author{
Elisangela Minati Gomide 2 , Paulo Borges Rodrigues 3 , Márcio Gilberto Zangeronimo ${ }^{4}$, \\ Antônio Gilberto Bertechini², Luziane Moreira dos Santos ${ }^{2}$, Renata Ribeiro Alvarenga²
}

\begin{abstract}
The objective of this study was to evaluate the effect of reduced-crude protein $(\mathrm{CP})$ and available phosphorus (aP) diets, added with phytase and amino acids for broilers in the growing (14 to 21 days old) and retirement ( 35 to 42 days) phases on nitrogen, potassium and phosphorus balance. Ninety Cobb broilers were distributed in a completely randomized design with three treatments and six replications with five and three birds per experimental unit in the growing and retirement phases, respectively. Diets were elaborated to contain reduced $\mathrm{CP}$ and aP levels $(19$ and $17 \% \mathrm{CP}$ in the growing phase, with $0.34 \%$ aP; and 18 and $16 \% \mathrm{CP}$ in the retirement phase, with $0.30 \% \mathrm{aP}$ ), supplemented with crystalline amino acids and $500 \mathrm{FTU}$ of phytase $/ \mathrm{kg}$ diet. These were compared to a control diet (21\% CP and $0.46 \%$ aP for growing phase and $19 \% \mathrm{CP}$ and $0.40 \%$ aP for retirement phase). The reduction of CP in four percentual units reduced the $\mathrm{N}$ excretion and increased the retention of this element, showing that the phytase had no influence on $\mathrm{N}$ balance when used the crystalline amino acids in the diets. The phytase reduced the $\mathrm{P}$ excretion and increased the retention ones. The potassium excretion decreased in reduced-CP diets, but this excessive reduction decreased the retention of this element, except in the retirement phase. It was concluded that the reduced-CP and aP diets, supplemented with phytase and amino acids, are efficient in reducing the pollutant power of the broilers excrements in the growing and retirement phases of production.
\end{abstract}

Index terms: Enzyme, phytate, environment, metabolism.

\section{RESUMO}

Objetivou-se, com este trabalho, avaliar o efeito de rações com reduzidos teores de proteína bruta (PB) e fósforo disponível (Pd), suplementadas com fitase e aminoácidos, para frangos de corte na fase de crescimento (14 a 21 dias) e terminação (35 a 42 dias de idade) sobre o balanço de nitrogênio, potássio e fósforo. Foram utilizados 90 pintos Cobb, distribuídos em um delineamento inteiramente casualizado com três tratamentos e seis repetições, com cinco e três aves por unidade experimental nas fases inicial e de crescimento, respectivamente. As rações foram formuladas para conterem níveis reduzidos de PB e Pd (19 e $17 \%$ de PB na fase de crescimento, com $0,34 \%$ de Pd e 18 e $16 \%$ de PB na fase de terminação, com 0,30\% de Pd) e suplementadas com aminoácidos e 500 FTU de fitase $/ \mathrm{kg}$ de ração Essas rações foram, então, que foram comparadas a uma ração controle ( $21 \%$ de PB e $0,46 \%$ de Pd para fase de crescimento e $19 \%$ de PB e $0,40 \%$ de Pd para fase de terminação). A redução da PB em quatro unidades percentuais reduziu a excreção, e aumentou a retenção de nitrogênio, mostrando que a fitase não interferiu no balanço de nitrogênio ao serem incluídos aminoácidos cristalinos nas rações. A excreção de potássio diminuiu em dietas com PB reduzida, mas esta redução em excesso diminuiu a retenção deste elemento, exceto na fase de retirada. Conclui-se que rações contendo níveis reduzidos de PB, cálcio e fósforo, suplementadas com fitase e aminoácidos, são eficientes em diminuir o poder poluente das excretas de frangos de corte.

Termos para indexação: Enzima, fitato, meio ambiente, metabolismo.

(Received in april 4, 2010 and approved in november 11, 2010)

\section{INTRODUCTION}

The increase in the amount of residues originating from avian activities has been reason of concern, mainly when the preservation of the environment is mentioned. This is evident in areas of intense production, where the excess of nutrients originating from the litter has been a problem, can damage the quality of the soil or water quality in these regions. The nitrogen, phosphorus and potassium are the main pollutant elements in the excrements of the birds.

Currently, nutritional strategies have been studied with the objective to improve the availability of nutrients of foods for the animals, reducing their elimination through excrements (Pucci et al., 2010). The application of the ideal protein concept, in which part of amino acids from the diet is substituted by crystalline amino acids, improves the capacity of the birds in retaining more nitrogen and

${ }^{1}$ Projeto financiado pelo CNPq com apoio da Fapemig

${ }^{2}$ Universidade Federal de Lavras/UFLA - Departamento de Zootecnia/DZO - Lavras, MG

${ }^{3}$ Universidade Federal de Lavras/UFLA - Departamento de Zootecnia/DZO - Cx. P. 3037 - 37200-000 - Lavras, MG - pborges@dzo.ufla.br

${ }^{4}$ Universidade Federal de Lavras/UFLA - Departamento de Medicina Veterinária/DMV - Lavras, MG 
potassium due to reduction of soybean meal in the diets. Several works have proven the benefits of this technique (Silva et al., 2008). With the availability of some amino acids produced in commercial scale, it is possible to elaborate reduced-crude protein diets for birds. According to these authors, it is possible to reduce the nitrogen excretion until $10 \%$ in birds that fed diets with one percent unit short in the crude protein.

Besides the reduction of the nitrogen quantity in the litter, researches show that the addition of phytase in the diets has been efficient in reducing the excretion of phosphorus by birds (Nagata et al., 2009). It is known that this enzyme can discharge the phosphorus of phytic acid during the digestive process, increasing its use by bird metabolism. However, besides this nutrient, others can also be available, like some minerals and even amino acids (Viveiros et al., 2002; Rutherfurd et al., 2004). Thus, the association of the use of the ideal protein concept in the elaboration of diets containing phytase cannot be efficient due to the amino acids unbalance concerned by use of the enzyme.

The association between the reduced-crude protein diets with crystalline amino acids and phytase has been little mentioned in literature. Thus, the objective of this work was to evaluate the effect of diets elaborated with reduced levels of crude protein and phosphorus, supplemented with phytase and crystalline amino acids, on the nitrogen, potassium and phosphorus balance in broilers in the growing and retirement phases.

\section{MATERIAL AND METHODS}

Two metabolism assays were conducted in the Poultry Sector of the Animal Science Department of the Federal University of Lavras, in Lavras, Minas Gerais, Brazil, using the traditional method of total collection of excrements.

Ninety Cobb broilers from 14 to 21 days of age (assay 1) and from 35 to 42 days (assay 2) were distributed in a totally randomized design with three treatments and six replications with five (assay 1) or three (assay 2) birds per experimental unit. The cages were constructed with galvanized wire $(50 \times 50 \times 50 \mathrm{~cm})$, containing a pressure drinking place, an individual type gutter plate with edge to prevent wastefulness and a tray coated with resistant plastic. The temperature of the room was controlled with automatic exhaust fans and the illumination was constant during all the experimental period ( 24 hours of artificial light).

After the accommodation in the cages, the birds remained four days in adaptation to the ad libitum experimental diets. Twenty four hours before the beginning of the period of excrement collection, the diets were weighed to measure the feed intake during the experimental phase, that was of three days, according to Rodrigues et al. (2005).
The experimental diets were elaborated with corn and soybean meal basis, supplemented with crystalline amino acids and 500 FTU of fitase/kg (Ronozyme - P5000), containing reduced crude protein and available phosphorus (Table 1). The amino acids ratio was maintained with regard to lysine following the ideal protein concept. These diets were compared to the control diet, elaborated by the requirements, according to Rostagno et al. (2000). All diets were isoenergetic in each poultry phase.

During the period of collection, the excrements were put in plastic bags, which were identified and stored in freezer until the final period of collection. At the end of this period, the total material collected was weighed, uniformed and a sample of approximately $400 \mathrm{~g}$ was kept for laboratorial analyses.

In the Animal Research Laboratory of the Animal Science Department / UFLA, one sample of each experimental unit were dried in a forced ventilation oven at $65^{\circ} \mathrm{C}$ during three days and then crushed in mill with 2.0 $\mathrm{mm}$ bolter. The dry matter and the nitrogen, potassium and phosphorus quantity in the diets and the excrements were measured.

For nitrogen, the Kjeldahl method, described by Silva \& Queiroz (2002), was utilized. For phosphorus, the colorimetric method was used and for potassium the flame photometer.

The nitrogen, calcium and phosphorus intake and excretion were determined in dry matter basis in the diet and excrements, respectively. To calculate the apparent retention coefficients (ACR) of these elements, the following formula was used:

$$
\mathrm{ARC}=\frac{\text { ingested nutrient }- \text { excreted nutrient }}{\text { ingested nutrient }} \times 100
$$

The obtained data were submitted to normality test (Shapiro Wilk) and to analisys of variance. The averages were compared by SNK test at 5\% when significant to F test. All the statistical analyses were led using Sisvar Statistics Program, described in Ferreira (2000).

\section{RESULTS AND DISCUSSION}

The reduction of the crude protein in the diets in four percent units reduced $(\mathrm{P}<0.05)$ the nitrogen intake, both in the growing and the retirement phases (Table 2). This was already expected, since most of this element proceeds from amino acids. However, the reduction in two units decreased the intake only in the growing phase. Probably, the biggest variation in the consumption in the retirement phase may have influenced these results. 
Table 1 - Percentual and calculated composition of the experimental diets.

\begin{tabular}{|c|c|c|c|c|c|c|}
\hline \multirow{2}{*}{ Ingredient } & \multicolumn{3}{|c|}{ Growing phase } & \multicolumn{3}{|c|}{ Retirement phase } \\
\hline & Control & $19 \% \mathrm{CP}$ & $17 \% \mathrm{CP}$ & Control & $18 \% \mathrm{CP}$ & $16 \% \mathrm{CP}$ \\
\hline Corn & 56.6 & 61.3 & 66.3 & 61.7 & 63.3 & 68.8 \\
\hline Soybean meal & 35.7 & 30.2 & 24.8 & 30.53 & 27.62 & 22.2 \\
\hline Soybean oil & 3.22 & 2.83 & 2.31 & 3.74 & 3.88 & 3.16 \\
\hline Dicalcium phosphate & 1.90 & 1.28 & 1.31 & 1.58 & 1.10 & 1.17 \\
\hline Limestone & 1.0 & 1.06 & 1.09 & 1.0 & 0.88 & 0.94 \\
\hline Sodium chloride & 0.50 & 0.50 & 0.50 & 0.48 & 0.48 & 0.48 \\
\hline L-lysine $\mathrm{HCl} 78 \%$ & 0.17 & 0.35 & 0.50 & 0.18 & 0.30 & 0.45 \\
\hline DL-methionine $99 \%$ & 0.23 & 0.28 & 0.33 & 0.20 & 0.24 & 0.28 \\
\hline L-valine $98 \%$ & 0.0 & 0.1 & 0.2 & 0.0 & 0.11 & 0.2 \\
\hline L-arginine $98 \%$ & 0.0 & 0.0 & 0.16 & 0.0 & 0.05 & 0.21 \\
\hline L-threonine $98 \%$ & 0.0 & 0.0 & 0.08 & 0.0 & 0.0 & 0.07 \\
\hline L-isoleucine $98 \%$ & 0.0 & 0.0 & 0.08 & 0.0 & 0.02 & 0.12 \\
\hline Vitamin $\operatorname{mix}^{1}$ & 0.045 & 0.045 & 0.045 & 0.035 & 0.035 & 0.035 \\
\hline Mineral mix ${ }^{1}$ & 0.05 & 0.05 & 0.05 & 0.05 & 0.05 & 0.05 \\
\hline Choline chloride $60 \%$ & 0.05 & 0.05 & 0.05 & 0.05 & 0.05 & 0.05 \\
\hline Salinomicin $12 \%$ & 0.021 & 0.021 & 0.021 & 0.021 & 0.021 & 0.021 \\
\hline Zinc bacitracin $15 \%$ & 0.01 & 0.01 & 0.01 & 0.01 & 0.01 & 0.01 \\
\hline Kaolim & 0.504 & 1.914 & 2.154 & 0.424 & 1.844 & 1.744 \\
\hline Phytase & 0.0 & 0.01 & 0.01 & 0.0 & 0.01 & 0.01 \\
\hline \multicolumn{7}{|l|}{ Calculated composition } \\
\hline Metabolizable energy(kcal/kg) & 3.000 & 3.000 & 3.000 & 3.100 & 3.100 & 3.100 \\
\hline Crude Protein $(\%)$ & 21.4 & 19 & 17 & 19.5 & 18 & 16 \\
\hline Available phosphorus (\%) & 0.45 & 0.34 & 0.34 & 0.40 & 0.30 & 0.30 \\
\hline Calcium $(\%)$ & 0.96 & 0.80 & 0.80 & 0.87 & 0.70 & 0.70 \\
\hline Potassium $(\%)$ & 0.83 & 0.74 & 0.65 & 0.75 & 0.7 & 0.61 \\
\hline Sodium (\%) & 0.23 & 0.23 & 0.23 & 0.23 & 0.23 & 0.23 \\
\hline Chlorine (\%) & 0.32 & 0.33 & 0.33 & 0.32 & 0.32 & 0.32 \\
\hline Electrolytic balance $(\mathrm{mEq} / \mathrm{kg})^{2}$ & 223 & 199 & 176 & 201 & 188 & 165 \\
\hline Digestible lysine (\%) & 1.15 & 1.15 & 1.15 & 1.04 & 1.04 & 1.04 \\
\hline Digestible methionine+cistine $(\%)$ & 0.81 & 0.81 & 0.82 & 0.74 & 0.74 & 0.74 \\
\hline Digestible valine (\%) & 0.87 & 0.88 & 0.89 & 0.8 & 0.85 & 0.85 \\
\hline Digestible arginine (\%) & 1.32 & 1.17 & 1.17 & 1.18 & 1.15 & 1.15 \\
\hline Digestible threonine (\%) & 0.71 & 0.64 & 0.65 & 0.64 & 0.6 & 0.6 \\
\hline Digestible isoleucine (\%) & 0.82 & 0.73 & 0.72 & 0.74 & 0.71 & 0.71 \\
\hline
\end{tabular}

${ }^{1}$ Vitamin and mineral premix includes the following per kilogram of diet: vitamin: vitamin $\mathrm{B}_{2}(12.000 \mathrm{mcg})$; vitamin $\mathrm{A}(30.000 .000$ $\mathrm{UI})$; vitamin $\mathrm{D}_{3}(6.000 .000 \mathrm{UI})$; vitamin $\mathrm{B}_{1}(6.000 \mathrm{mg})$; vitamin $\mathrm{B}_{6}(12.000 \mathrm{mg})$; vitamin $\mathrm{B}_{12}(60.000 \mathrm{mcg})$; biotin $(240 \mathrm{mcg})$; folic acid (3.000 mcg); pantothenic acid (30.000 mcg); vitamin $\mathrm{K}_{3}(8.000 \mathrm{mg})$; vitamin $\mathrm{E}$ (60.000 mg); zinc (110.000 mg); iron (96.00 $\mathrm{mg}$ ); copper (20.000 mg); manganese (156.000 mg), iodine (1.400 mg) and selenium (360 mg).

${ }^{2}$ Calculated according to Mongin (1981): $\mathrm{Na}+\mathrm{K}-\mathrm{Cl}$. 
Table 2 - Nitrogen balance in growing and retirement broilers receiving diets with reduced crude protein, calcium and phosphorus, supplemented with amino acids and phytase.

\begin{tabular}{|c|c|c|c|c|}
\hline \multirow{2}{*}{ Variable } & \multicolumn{3}{|c|}{ Experimental diets } & \multirow{2}{*}{$\mathrm{CV}(\%)$} \\
\hline & Control $^{1}$ & Reduced plan $1^{2}$ & Reduced plan $2^{2}$ & \\
\hline \multicolumn{5}{|c|}{ - Growing phase - } \\
\hline $\mathrm{N}$ consumed $(\mathrm{mg} / \mathrm{d})$ & $3,177 \mathrm{a}$ & $2,958 \mathrm{~b}$ & $2,638 \mathrm{c}$ & 3.57 \\
\hline $\mathrm{N}$ excreted (mg/d) & $1,200 \mathrm{a}$ & $1,035 \mathrm{~b}$ & $920 \mathrm{c}$ & 5.97 \\
\hline $\mathrm{N}$ retained $(\%)$ & $62.24 \mathrm{~b}$ & $65.00 \mathrm{a}$ & $65.05 \mathrm{a}$ & 3.04 \\
\hline \multicolumn{5}{|c|}{ - Retirement phase - } \\
\hline $\mathrm{N}$ consumed (mg/d) & $5,559 \mathrm{a}$ & $5,409 \mathrm{a}$ & $4,790 \mathrm{~b}$ & 6.39 \\
\hline $\mathrm{N}$ excreted (mg/d) & $2,115 \mathrm{a}$ & $2,116 \mathrm{a}$ & $1,696 \mathrm{~b}$ & 8.63 \\
\hline $\mathrm{N}$ retained (\%) & $61.94 \mathrm{~b}$ & $60.91 \mathrm{~b}$ & $64.58 \mathrm{a}$ & 3.11 \\
\hline
\end{tabular}

${ }^{1}$ Growing phase: $21 \% \mathrm{CP}, 0.45 \% \mathrm{aP}$ and $0.96 \% \mathrm{Ca}$; Retirement phase: $20 \% \mathrm{CP}, 0.40 \%$ aP and $0.87 \% \mathrm{Ca}$.

${ }^{2}$ Growing phase: $19 \% \mathrm{CP}, 0.34 \% \mathrm{aP}$ and $0.80 \% \mathrm{Ca}$; Retirement phase: $18 \% \mathrm{CP}, 0.30 \% \mathrm{aP}$ and $0.70 \% \mathrm{Ca}$.

${ }^{3}$ Growing phase: $17 \% \mathrm{CP}, 0.34 \%$ aP and $0.80 \% \mathrm{Ca}$; Retirement phase: $16 \% \mathrm{CP}, 0.30 \% \mathrm{aP}$ and $0.70 \% \mathrm{Ca}$.

${ }^{\mathrm{a}, \mathrm{b}}$ Means following by different letters in the line differ by SNK test $(\mathrm{P}<0.05)$.

The reduction of the crude protein of the diets decreased the total amino acid intake, considering mainly the not essential ones, since the essential amino acids were added following the ideal protein concept.

The nitrogen excretion by birds following $(\mathrm{P}<0.05)$ the results of nitrogen intake, in other words, the lower intake decreased the elimination. This occurred because the main amino acids had been supplemented when there was a reduction in the crude protein level in the diets. Thus, these amino acids did not limit the protein synthesis. It is known in the literature that the lack of an essential amino acid increases the nitrogen elimination by birds, due to the non use of the other amino acids. This can favor the uric acid synthesis by animal metabolism.

In the present work, it was observed that the birds in growing phase that received 19 and $17 \% \mathrm{CP}$ diets eliminated 14 and $23 \%$ less nitrogen, respectively, in relation to the birds that received the control diet $(21 \% \mathrm{CP})$. This represents a decrease of $5.5 \%$ in the nitrogen absolute excretion to each percentage point reduced from the crude protein in the diet in this phase. As to the retirement phase, a reduction of $20 \%$ of nitrogen absolute excretion was verified when the crude protein of the diets was reduced from 19 (control) to $16 \%$. Considering the reduction per percentage point of decrease of crude protein, there was a reduction of $6 \%$ in the nitrogen excretion.

These results confirm the ones obtained by Silva et al. (2008), showing that the reduction of the protein levels of the diets can be beneficial in minimizing the environmental impact caused by the nitrogen excess in the excrements. However, the nitrogen excretion shown in the present work was less significant than the one presented by these authors. This can be related to the time the experiment was performed. Moreover, different intensity of immune system activation can also influence the capacity of the birds in retaining the nutrients, generating controversial results in literature (Oliveira Neto \& Oliveira, 2009).

Considering the growing phase, the coefficient of nitrogen retention was similar among the birds that received 17 and $19 \%$ CP diets, however was superior $(\mathrm{P}<0.05)$ in regard to the birds that received the control diets. As to the retirement phase, the higher protein reduction of the diet resulted in higher retention, confirming the good use of nitrogen by birds and the adequate amino acid balance propitiated by the crystalline amino acid inclusion. These results were similar to the ones obtained by Faria Filho et al. (2005), both in birds bred in thermoneutral environment as and in high or low temperature.

These results show that the inclusion of phytase does not influence significantly the nitrogen balance in birds that receive balanced-crystalline amino acids diets. Thus, this enzyme can be used to reduce the excretion of other elements. According to Mroz et al. (1994), the phytic acid could be related to enzymes in the gastrointestinal tract, such as trypsin and pepsin. This can influence the protein digestibility, changing the amino acid balance of the diet. Still, Camden et al. (2001) evidenced that the apparent nitrogen retention in broilers increased with the phytase addition in corn-soybean meal diets. Increases of 
the amino acids use in diets with phytase were also observed in experiments conducted by Sebastian et al. (1997). According to Costa et al. (2007), these results can be linked to the type of enzyme used in these works.

The phosphorus reduction in the diets decreased $(\mathrm{P}<0.05)$ the intake of this element by growing birds (Table 3). However, the reduction of the crude protein from 19 to $17 \%$, keeping the levels of available phosphorus, reduced the intake even more, resulting $(\mathrm{P}<0.05)$ in lower excretion of this element. This result can be linked to the lower intake of diets by birds that received the lower crude protein diets (17\% CP), since the adequate amino acids balance favors the lower energy expense for the uric acid synthesis.

Still in the growing phase, higher phosphorus retention was observed $(\mathrm{P}<0.05)$ in the birds that received reduced-crude protein diets. This result can be linked to the phytase activities that discharge, from the diet, this element to the animals and the hormonal regulation, probably due to the lower diet intake. The effect of phytase is known for increasing the phosphorus availability to birds deriving vegetable diets (Nagata et al., 2009; Lan et al., 2010).

In the present work, when the crude protein of the diets for growing broilers was reduced from 21 to $17 \%$ and the available phosphorus from 0.45 to $0.34 \%$ there was improvement of $27 \%$ in the phosphorus retention coefficient and reduction of $53 \%$ in the absolute excretion of this element. As for the retirement phase, this effect was less expressive, of $13 \%$ in retention and $20 \%$ in the excretion. This result opposes to that obtained by Brandão et al. (2007), which concludes that the phytase is not necessary in the final phase of bird breeding.

The improvement in phosphorus digestibility and utilization is expected because the phytase promotes hydrolysis of the phytic acid-mineral complex, leaving the phosphorus free for absorption, thus decreasing its excretion (Lan et al., 2010).

The reduction of the crude protein in the diets resulted in lower potassium intake by birds $(\mathrm{P}<0.05)$, that was already expected, since there was a reduction of the soybean meal with the crystalline amino acid inclusion (Table 4). The birds that received $19 \% \mathrm{CP}$ diets eliminated less potassium $(\mathrm{P}<0.05)$ and had the coefficient of retention similar to birds that received control diet. This demonstrates that the reduction of the protein level in the diet for this level, in other words, with a smaller amount of soybean meal, which is considered the main diet potassium source, did not prejudice the retention of this mineral. However, the reduction of the protein level to $17 \%$ reduced $(\mathrm{P}<0.05)$ the potassium retention.

This lower excretion can be associated to both the low intake and the contribution of the phytase enzyme in order to improve the potassium availability of the ingredients used in the diets for the birds.

In accordance to Ravindran et al. (2000) the birds present the capacity to increase the necessary mineral retention to keep the physiological functions when their levels are reduced in the diet. However, the extreme reduction observed in $17 \% \mathrm{CP}$ diets, which corresponded to $30 \%$ of reduction of soybean meal, prejudiced the retention of this element by birds.

Table 3 - Phosphorus balance in growing and retirement broilers receiving diets with reduced crude protein, calcium and phosphorus, supplemented with amino acids and phytase.

\begin{tabular}{|c|c|c|c|c|}
\hline \multirow{2}{*}{ Variable } & \multicolumn{3}{|c|}{ Experimental diets } & \multirow{2}{*}{$\mathrm{CV}(\%)$} \\
\hline & Control $^{1}$ & Reduced plan $1^{2}$ & Reduced plan $2^{2}$ & \\
\hline \multicolumn{5}{|c|}{ - Growing phase - } \\
\hline$P$ consumed $(\mathrm{mg} / \mathrm{d})$ & $556 \mathrm{a}$ & $459 \mathrm{~b}$ & $352 \mathrm{c}$ & 3.57 \\
\hline $\mathrm{P}$ excreted (mg/d) & $288 \mathrm{a}$ & $214 b$ & $136 \mathrm{c}$ & 13.32 \\
\hline $\mathrm{P}$ retained $(\%)$ & $48.13 \mathrm{~b}$ & $53.38 \mathrm{~b}$ & $61.24 \mathrm{a}$ & 10.72 \\
\hline \multicolumn{5}{|c|}{ - Retirement phase - } \\
\hline$P$ consumed $(\mathrm{mg} / \mathrm{d})$ & $966 \mathrm{~b}$ & $1,060 \mathrm{a}$ & $826 \mathrm{c}$ & 6.67 \\
\hline P excreted (mg/d) & 658 a & $582 \mathrm{~b}$ & $529 \mathrm{~b}$ & 12.35 \\
\hline $\mathrm{P}$ retained $(\%)$ & $31.90 \mathrm{~b}$ & $45.08 \mathrm{a}$ & $35.94 \mathrm{~b}$ & 15.51 \\
\hline
\end{tabular}

${ }^{1}$ Growing phase: $21 \% \mathrm{CP}, 0.45 \%$ aP and $0.96 \% \mathrm{Ca}$; Retirement phase: $20 \% \mathrm{CP}, 0.40 \% \mathrm{aP}$ and $0.87 \% \mathrm{Ca}$.

${ }^{2}$ Growing phase: $19 \% \mathrm{CP}, 0.34 \% \mathrm{aP}$ and $0.80 \% \mathrm{Ca}$; Retirement phase: $18 \% \mathrm{CP}, 0.30 \% \mathrm{aP}$ and $0.70 \% \mathrm{Ca}$.

${ }^{3}$ Growing phase: $17 \% \mathrm{CP}, 0.34 \%$ aP and $0.80 \% \mathrm{Ca}$; Retirement phase: $16 \% \mathrm{CP}, 0.30 \%$ aP and $0.70 \% \mathrm{Ca}$.

a,b Means following by different letters in the line differ by SNK test $(\mathrm{P}<0.05)$ 
Table 4 - Potassim balance in growing and retirement broilers receiving diets with reduced crude protein, calcium and phosphorus, supplemented with amino acids and phytase.

\begin{tabular}{|c|c|c|c|c|}
\hline \multirow{2}{*}{ Variable } & \multicolumn{3}{|c|}{ Experimental diets } & \multirow[b]{2}{*}{$\mathrm{CV}(\%)$} \\
\hline & Control $^{1}$ & Reduced plan $1^{2}$ & Reduced plan $2^{2}$ & \\
\hline \multicolumn{5}{|c|}{ - Growing phase - } \\
\hline K consumed $(\mathrm{mg} / \mathrm{d})$ & $1,062 \mathrm{a}$ & $954 b$ & $815 \mathrm{c}$ & 3.57 \\
\hline $\mathrm{K}$ excreted (mg/d) & $547 \mathrm{a}$ & $501 \mathrm{~b}$ & $506 \mathrm{~b}$ & 4.75 \\
\hline $\mathrm{K}$ retained $(\%)$ & $48.44 \mathrm{a}$ & $47.46 \mathrm{a}$ & $37.89 \mathrm{~b}$ & 5.02 \\
\hline \multicolumn{5}{|c|}{ - Retirement phase - } \\
\hline $\mathrm{K}$ consumed $(\mathrm{mg} / \mathrm{d})$ & $1,813 \mathrm{a}$ & $1,687 \mathrm{~b}$ & $1,430 \mathrm{c}$ & 6.39 \\
\hline $\mathrm{K}$ excreted (mg/d) & $1,087 \mathrm{a}$ & $1,153 \mathrm{a}$ & $709 \mathrm{~b}$ & 11.4 \\
\hline $\mathrm{K}$ retained $(\%)$ & $39.86 \mathrm{~b}$ & $31.55 \mathrm{~b}$ & $50.36 \mathrm{a}$ & 16.23 \\
\hline
\end{tabular}

${ }^{1}$ Growing phase: $21 \% \mathrm{CP}, 0.45 \% \mathrm{aP}$ and $0.96 \% \mathrm{Ca}$; Retirement phase: $20 \% \mathrm{CP}, 0.40 \%$ aP and $0.87 \% \mathrm{Ca}$.

${ }^{2}$ Growing phase: $19 \% \mathrm{CP}, 0.34 \% \mathrm{aP}$ and $0.80 \% \mathrm{Ca}$; Retirement phase: $18 \% \mathrm{CP}, 0.30 \% \mathrm{aP}$ and $0.70 \% \mathrm{Ca}$.

${ }^{3}$ Growing phase: $17 \% \mathrm{CP}, 0.34 \% \mathrm{aP}$ and $0.80 \% \mathrm{Ca}$; Retirement phase: $16 \% \mathrm{CP}, 0.30 \% \mathrm{aP}$ and $0.70 \% \mathrm{Ca}$.

${ }^{\mathrm{a}, \mathrm{b}}$ Means following by different letters in the line differ by SNK test $(\mathrm{P}<0.05)$.

In the retirement phase it had lower intake, lower excretion and higher potassium retention coefficient when the birds received $16 \% \mathrm{CP}$ diets, if compared to those which received the control diet and $18 \% \mathrm{CP}$ diets.

These results demonstrate that the lower the presence of nutrients in the diets and the greater their necessity by the birds, the greater the retention efficiency. This also demonstrates that diets without additives for birds contain excess of nutrients that are eliminated through excrements, contaminating the environment. The reduction of the protein level in the diets to $18 \%$ was not enough to reduce the excretion of potassium, even with phytase addition. However, the birds that received $16 \% \mathrm{CP}$ diets reduced the excretion and increased the capacity of retention of this mineral. This suggests the presence of mechanisms that control the absorption of this element in the gastrointestinal tract of the birds.

These results point how possible it is to reduce the emission of these pollutant elements by birds through the diet manipulation, applying the ideal protein concept and including phytase to correct the calcium and phosphorus levels in the diets.

\section{CONCLUSIONS}

The manipulation of the diets reducing the crude protein, calcium and available phosphorus levels, supplemented with phytase and amino acids is efficient in reducing the pollutant power of broiler excrements in the growing and retirement phases of production.

\section{REFERENCES}

BRANDÃO, P.A.; COSTA, P.G.P.; BRANDÃO, J.S.; SILVA, J.H.V. Efeito da adição de fitase em rações de frangos de corte, durante as fases de crescimento e final. Ciência e Agrotecnologia, Lavras, v.31, n.2, p.492-498, 2007.

CAMDEN, B.J.; MOREL, P.C.H.; THOMAS, D.V.; RAVINDRAN, V.; BEDFORD, M.R. Effectiveness of exogenous microbial phytase in improving the bioavailabilities of phosphorus and other nutrients in maize: soya-bean meal diets for broilers. Animal Science, Cambridge, v.73, n.2, p.289-297, 2001.

COSTA, F.G.P.; BRANDÃO, P.A.; BRANDÃO, J.S.; SILVA, J.H.V. Efeito da enzima fitase nas rações de frangos de corte, durante as fases pré-inicial e inicial. Ciência e Agrotecnologia, Lavras, v.31, n.3, p.865-870, 2007.

FARIA FILHO, D.E.; ROSA, P.S.; VIEIRA, B.S.; MACARI, M.; FURLAN, R.L. Protein levels and environmental temperature effects on carcass characteristics, performance, and nitrogen excretion of broiler chickens from 7 to 21 days of age. Revista Brasileira de Ciência Avícola, Campinas, v.7, n.4, p.247-253, 2005.

FERREIRA, D.F. Análises estatísticas por meio do Sisvar para Windows versão 4. 0. In: REUNIÃO ANUAL DA REGIÃO BRASILEIRA DA SOCIEDADE

INTERNACIONAL DE BIOMETRIA, 45., 2000, São

Carlos. Anais... São Carlos: UFSCar, 2000. p.255-258. 
LAN, G.Q.; ABDULLAH, N.; JALALUDINC, S.; HO, Y.W. In vitro and in vivo enzymatic dephosphorylation of phytate in maize-soya bean meal diets for broiler chickens by phytase of Mitsuokella jalaludinii. Animal Feed

Science and Technology, Amsterdam, v.158, p.155-164, 2010.

MONGIN, P. Recent advances in dietary anion-cation balance: application in poultry. Proceeding. Nutrition Society, Wallingford, v.40, n.3, p.285-294, 1981.

MROZ, Z.; JONGBLOED, A.W.; KEMME, P.A. Apparent digestibility and retention of nutrients bound to phytate complexes as influenced by microbial phytase and feeding regimen in pigs. Journal of Animal Science, Champaign, v.72, n.1, p.126-132, 1994.

NAGATA, A.K.; RODRIGUES, P.B.; RODRIGUES, K.F.; FREITAS, R.T.F.; ALBINO, L.F.T.; FIALHO, E.T. Uso do conceito de proteína ideal em rações com diferentes níveis energéticos, suplementadas com fitase para frangos de corte de 1 a 21 dias de idade. Ciência e Agrotecnologia, Lavras, v.33, n.2, p.599-605, 2009.

OLIVEIRA NETO, A.R.; OLIVEIRA, W.P. Aminoácidos para frangos de corte. Revista Brasileira de Zootecnia, Viçosa, v.38, p.205-208, 2009. Suplemento especial.

PUCCI, L.E.A.; RODRIGUES, P.B.; FREITAS, R.T.F.de; FIALHO, E.T.; NASCIMENTO, G.A.J.do; ALVARENGA, R.R. Efeito do processamento, suplementação enzimática e nível nutricional da ração para frangos de corte no período de 22 a 42 dias de idade. Ciência e Agrotecnologia, Lavras, v. 34, n. 6, p. 15571565,Nov./dez., 2010.

RAVINDRAN, V.; CABAHUG, S.; RAVINDRA, G.; SELLE, P.H.; BRYDEN, W.L. Response of broilers to microbial phytase supplementation as influenced by dietary phytic acid and non-phytate phosphorus levels: II., effects on nutrient digestibility and retention. British Poultry Science, Edinburg, v.41, n.2, p.193-200, 2000.
RODRIGUES, P.B.; MARTINEZ, R.S.; FREITAS, R.T.F.; BERTECHINI, A.G.; FIALHO, E.T. Influência do tempo de coleta e metodologias sobre a digestibilidade e o valor energético de rações para aves. Revista Brasileira de Zootecnia, Viçosa, v.34, n.3, p.882-889, 2005.

ROSTAGNO, H.S.; ALBINO, L.F.T.; DONZELE, J.L.; GOMES, P.C.; FERREIRA, A.S.; OLIVEIRA, R.F.; LOPES, D.C. Tabelas brasileiras para aves e suínos: composição de alimentos e exigências nutricionais. Viçosa, MG: UFV, 2000. 141p.

RUTHERFURD, S.M.; CHUNG, T.K.; MOREL, P.C.H.; MOUGHAN, P.J. Effect of microbial phytase on ideal digestibility of phytase phosphorus, total phosphorus, and amino acids in a low-phosphorus diet for broilers. Poultry Science, Champaign, v.83, n.1, p.61-68, 2004.

SEBASTIAN, S.; TOUCHBURN, S.P.; CHAVEZ, E.R.; LAGUE, P.C. Apparent digestibility of protein and amino acids in broiler chickens fed a corn-soybean diet supplemented with microbial phytase. Poultry Science, Champaign, v.76, n.12, p.1760-1769, 1997.

SILVA, D.J.; QUEIROZ, A.C. Análise de alimentos: métodos químicos e biológicos. 3.ed. Viçosa, MG: UFV, 2002. 235p.

SILVA, Y.L.; RODRIGUES, P.B.; FREITAS, R.T.; ZANGERONIMO, M.G.; FIALHO, E.T. Níveis de proteína e fósforo em rações com fitase para frangos de corte, na fase de 14 a 21 dias de idade: 2., valores energéticos e digestibilidade de nutrientes. Revista Brasileira de Zootecnia, Viçosa, v.37, n.3, p.469-477, 2008.

VIVEIROS, A.; BRENES, A.; ARIJA, I.; CENTENO, C. Effects of microbial phytase supplementation on mineral utilization and serum enzyme activities in broiler chicks fed different levels of phosphorus. Poultry Science, Champaign, v.81, n.8, p.1172-1183, 2002. 